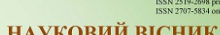

Scientific messenger of Lviv National Univeris of

Sison

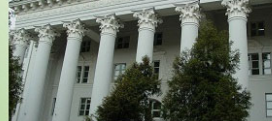

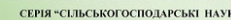

(3)

2021
Науковий вісник Яьвівського національного університету ветеринарної медицини та біотехнодогій імені С.3. Гжицького. Серія: Сільськогосподарські науки

\author{
Scientific Messenger of Lviv National University
} of Veterinary Medicine and Biotechnologies. Series: Agricultural sciences

UDC 639.33( 477.411)

\title{
Fundamentals of commodity fishery for the cultivation of silver carp in polyculture with carp in the conditions of the LLC "Kovcheg" of the Kyiv
}

\author{
V. Palamarchuk, G. Lyotka, V. Hlavatchuk \\ Vinnytsia National Agrarian University, Vinnytsia, Ukraine
}

Article info

Received 17.05.2021

Received in revised form 21.06.2021

Accepted 22.06.2021

Vinnytsia National Agrarian University, Soniachna Str.,3, Vinnytsia, 21000, Ukraine. Tel: $+38-063-228-16-03$ E-mail:vladvladp95@gmail.com
Palamarchuk, V., Lyotka, G., \& Hlavatchuk, V. (2021). Fundamentals of commodity fishery for the cultivation of silver carp in polyculture with carp in the conditions of the LLC "Kovcheg" of the Kyiv. Scientific Messenger of Lviv National University of Veterinary Medicine and Biotechnologies. Series: Agricultural sciences, 23(95), 87-95. doi: 10.32718/nvlvet-a9513

This scientific article describes the technology and stages of designing a fishery for growing silver carp in polyculture with carp in conditions of the LLC "Kovcheg" of the Kyiv. In the conditions of this economy the project of cultivation of fish in polyculture was developed, where calculations of average monthly temperature of ponds, content of dissolved oxygen in water were carried out, indicators of a source of water supply of ponds were analyzed, economic efficiency of cultivation of silver carp in polyculture with carp was carried out. Fish farms have a number of significant problems today, that prevent full and easy development - these are financial difficulties in the state, namely: disruption of economic ties, deterioration of the ecological condition of inland waters, insufficient work on the reproduction of fish stocks. In order to get fish farming out of the crisis, ensure sustainable development of the industry, strengthen the country's food independence, it is necessary first of all to solve issues related to environmental and economic problems of fisheries development, improving the economic mechanism of fisheries management, intensification of investment processes and innovations aquatic living resources. The fisheries sector includes the extraction, processing, reproduction and increase of stocks of fish and other aquatic organisms in natural and artificial reservoirs. It provides valuable food, feed, medicine and technical products. Fisheries are aimed at preserving and improving fish stocks in natural reservoirs and breeding fish in artificial reservoirs. In order to ensure food security of Ukraine, it is necessary to work on the following areas: scientific substantiation of the raw material base and rational fishing, protection of aquatic ecosystems, technology of processing of aquatic fish resources.

Key words: compound feed industry, effectiveness, productivity, silver carp, polyculture.

\section{Основи ведення товарного рибного господарства з вирощування товстолоба в полікультурі з коропом в умовах ТОВ “Ковчег” міста Києва}

\author{
В. Я. Паламарчук, Г. І. Льотка, В. А. Главатчук
}

Вінницький наџฺіональний аграрний університет, м. Вінниця, Украӥна

У иій науковій статті описана технологія та етапи проектування промислу для вирощування товстолобика в полікультурі з коропом в умовах ТОВ “Ковчег” м. Києва. В умовах даного господарства був розроблений проект вирочування риби в полікультурі, де проводились розрахунки середньомісячної температури ставків, вмісту розчиненого у воді кисню, аналізувались показники джерела водопостачання ставків, економічна ефективність вирошування товстолобика в полікультурі з коропом. На сьогоднішній день у рибних господарств є низка суттєвих проблем, шо перешкоджають повноцінному та легкому розвитку - ие фінансові трудноші в державі, а саме: порушення економічних зв'язків, погіршення екологічного стану внутрішніх вод, недостатня робота з відтворення рибних запасів. Щоб вивести рибництво з кризи, забезпечити стійкий розвиток галузі, зміцнити продовольчу незалежність країни, перш за все необхідно вирішити питання, пов'язані з екологічними та економічними проблемами розвитку рибного господарства, вдосконалення економічного механізму управління рибальством, активізаиії інвестииійних проиесів та інновачій, раціонального використання природних водних живих ресурсів. Рибний сектор включає видобуток, переробку, відтворення та 
збільшення запасів риби та інших водних організмів у природних та штучних водоймах. Він забезпечує людство иінною їжею, корми, ліки та технічну продукцію. Рибальство спрямоване на збереження та поліпшення рибних запасів у природних водоймах та розведення риби у штучних водоймах. 3 метою організачії продовольчої безпеки Украӥни необхідно попрачювати за такими напрямами: наукове обтрунтування сировинної бази та раціональний промисел, охорона водних екосистем, технологія переробки водних рибних ресурсів.

Ключові слова: комбікормова промисловість, ефективність, продуктивність, товстолобик, полікультура.

\section{Introdaction}

This topic is quite relevant today, because fisheries industry provide fisheries, as well as technologically related enterprises and organizations or other enterprises that ensure the activities and development of the industry (sea fishing ports, industry schools, training centers, research, design and engineering enterprises and organizations, shipbuilding, ship repair plants, breeding centers, specialized laboratories (Grynevych et al., 2018; Bobel et al., 2018; Prysiazhniuk et al., 2019; Burgaz et al., 2019; Rudenko et al., 2019; Burhaz et al., 2020).

Due to the annexation of Crimea, Ukraine has lost a significant share of the catch. In the current situation, there was a need to identify reserves for the development of the industry, in particular the search for new economically justified methods of pond fish farming with the use of the complex resource-saving measures for the operation of ponds and fish keeping, as well as the development and introduction of a progressive system of rational exploitation of aquatic bioresources, aimed at significantly improving the efficiency of bioproductive potential reservoirs. These circumstances encourage a comprehensive revision of the regulatory and technological parameters of pond fish farming and a number of basic theoretical provisions regarding its conduct (Mushit \& Datsyuk, 2020; Datsyuk \& Mushit, 2020).

In order to get fish farming out of the crisis, ensure sustainable development of the industry, strengthen the country's food independence; it is necessary first of all to solve issues related to environmental and economic problems of fisheries development, improving the economic mechanism of fisheries management, intensification of investment processes and innovations aquatic living resources.

Every year there is a tendency to reduce the cultivation of various species of fish in Ukraine. An alternative way out of this situation is to grow fish in multiculture. In polyculture, you can grow several species of fish, which is economically viable and profitable for farms.

Additional planting in carp ponds of fish of other species allows the most complete use of natural resources of ponds. Since the 60's, together with the carp in the ponds began to grow fish of the Far Eastern complex white and variegated silver carp, their hybrids and grass carp. Herbivorous fish have made polyculture a leading factor in intensification.

There was a decrease in feed costs by 30-45\% at various combinations of polyculture of carp with herbivorous fish and hybrids of silver carp. In addition, there was a high plasticity of hybrids of silver carp in the diet, which in the absence of zooplankton in the ponds switched to phytoplankton and vice versa. Increasing the productivity of feeding ponds due to white herring can be solved both by increasing the planting density and the initial planting mass; when growing carp with hybrids of silver carp, their ratio in polyculture can be $1: 1$.

Over the past 30 years, per capita consumption of fish and fish products in our country has never met the norm. It ranged from 18 to $87.5 \%$ of demand. This situation undermined the country's food security, reduced consumption, taking into account the energy and physiological needs of man (Vovk \& Bozhyk, 2014).

The main reason for insufficient consumption of fish and fish products was and production lag remains these products from the needs of the population. During the transition of the country's economy to new forms of production fish and fish products decreased significantly, which affected their consumption. So, in 1990, the actual consumption of fish and fish products per capita was $17.5 \mathrm{~kg}$ per year, or $87.5 \%$ of demand, then in 1995 only $3.6 \mathrm{~kg}$, in $2000-8.4 \mathrm{~kg}$ and only since 2007 began to grow and was $15.3 \mathrm{~kg}$, or $76.5 \%$ of demand. In 2009 , the fund for the consumption of fish and fish products increased to 697 thousand tons, or $15.1 \mathrm{~kg}$ per capita. Fishing and extraction of other aquatic living resources in Ukraine in 2009 reached 256.8 thousand tons, and imports to Ukraine -450.7 thousand tons, or 2.4 times higher than own production we take into account consumption, then from $15.1 \mathrm{~kg}$ of fish and fish products consumed in 2009, almost $10 \mathrm{~kg}$ were imported by import and only $5.1 \mathrm{~kg}$ of own production. Imports account for $64.7 \%$ as well permissible for food preservation national security only $30 \%$ (Mukhina, 2008; Gritsinyak et al., 2011).

We paid special attention on intensification of pond fish farming. Methods of intensification and their implementation in pond fish farming developed in the first half of the twentieth century. Professor V. Movchan. As a result of studying the factors that contribute to increasing the fish productivity of ponds, allowed him to install them. A special place is occupied by implementation polyculture as a factor of intensification pond fish farming. The vast majority of scientists have studied the issue joint cultivation of carp and herbivorous fish. Other species of fish almost not used, resulting fish multiculture was impoverished and not gave a significant effect.

Common carp (Cyprinus carpio) is a common freshwater commercial fish of the carp family. It is usually characterized as an alien species native to Asia. Introduced to many parts of the world, managed to naturalize in the waters of Europe. The domesticated form of this fish is one of the most common commercial fish in fish farms in size, the decorative form of domesticated carp is brocade carp.

Naturalized in "wild" reservoirs carp have some external differences from the "pond" forms of carp, because of this in some regions of Ukraine has taken root borrowed from the Russian tradition for wild forms - carp (Sazan, Turkish Sazan). 
Carp body length - up to $1 \mathrm{~m}$, live weight can reach more than $20 \mathrm{~kg}$. The largest individuals reach more than $45 \mathrm{~kg}$ (current world record for 2019 - $48 \mathrm{~kg}$ ) (Sherman \& Yevtushenko, 2011).

In the climatic conditions of Ukraine it becomes sexually mature in the southern regions in the third or fourth years of life, in Polissya - Forest-Steppe - in the fourth-fifth. Males mature a year earlier than females. The broods are most productive at the age of 6 to 9-11 years, after which they are culled. Fertility of carp is mostly from 600 thousand to more than 1.5 million eggs. From one female in the conditions of natural spawning it is possible to receive on the average to 200 thousand and more 3-4 day-old larvae. Under natural conditions, carp spawn at a water temperature of $+17-20{ }^{\circ} \mathrm{C}$ in coastal areas of water bodies covered with soft meadow vegetation, which is used by it as a substrate for incubation of sticky eggs.

Carp has significant trophic plasticity (the ability to switch to new food in the absence of the usual food). In the early stages of development feeds on zooplankton. In the first days the fry consume its small forms (rotifers, moins), and later switch to the consumption of larger forms of zooplankton (daphnia, ceriodaphnia, cyclops, etc.). At the end of the growing season in the first year of life passes to the consumption of zoobenthos organisms, in older age groups carp is dominated by zoobenthos organisms (chironomid larvae, oligochaetes, mollusks).

With their deficiency, it switches to feeding on other aquatic organisms, including large forms of zooplankton, macrophytes, and detritus; well adapted to eating feed and cereals (Geiko, 2010).

Silver Capr Distributed mainly in the Amur River basin and recently spread to major rivers in Europe and Asia Minor. Because of the passion for eating algae in large quantities, silver carp is called "river cow". Due to the same quality, silver carp artificially stock lakes and ponds to clear them of excess greenery. Of these, the population of the species has spread to the Dnieper and its reservoirs.

The length of an adult silver carp reaches 1 meter, and the weight is mostly not more than $40 \mathrm{~kg}$. Sexual maturity of silver carp occurs at the age of 3-4 years. They feed mainly on small algae in shallow water. For the winter they go into hibernation in "wintering pits".

An important food product in the food industry for the production of canned fish economy class. There is no natural population of silver carp in Ukraine. Recently, however, silver carp have been caught in the Dnieper, Kamyansk, Kaniv, Kakhovka, Kyiv, and Kremenchug reservoirs weighing up to 60 kilograms, which is unnatural for this species.

With the help of its oral apparatus, the white silverfish filters moldy, green and turbid water from detritus. In nature, during the winter it goes into hibernation in the depths of slow rivers. They feed mainly on small algae in shallow water. The first days after the transition to active nutrition, he consumes zooplankton, but after reaching 16 $\mathrm{mm}$ also begins to feed on phytoplankton. Soon phytoplankton - small, low-calorie, but available in large quantities of food - becomes the only source of food for silver carp.
According to I. Sherman and M. Yevtushenko, the use of new fish farms and their acclimatization is one of the important elements that ensure the intensive development of various forms of fisheries in inland waters. The silver carp is a good example of ichthyofaunal, it increases fish productivity of fish farms almost 2 times (Sherman \& Yevtushenko, 2011).

The development of theoretical foundations of polyculture using herbivorous fish was started in 1965. In studies to improve the biotechnology of the pond polyculture of fish, the primary role was given to white herring as a direct consumer of primary products, the level of which could be regulated by mineral fertilizers.

Studies have shown the possibility of simultaneous sustainable cultivation of fish and organisms of other trophic levels. In such a system there are opportunities to increase the biological productivity of all its parts, feed is used efficiently and the biological purification of circulating water is successfully carried out (Vlasov \& Mustaev, 2004).

The inclusion of the phytoplankton block in the system allowed to obtain algae products for the period of fish farming, which amounted to up to $15 \%$ of the consumed feed in energy equivalent. The zooplankton block made it possible to enrich the daily diet of fish with live whole food, which is up to $10 \%$ of the daily norm of feed. Restoration of the source of natural food for carp allowed to reduce the cost of artificial feed per unit of fish production from 8.5 to 5 units. The high level of intensification led to the complete disappearance of macrophytes in the pond ecosystem (Mukhina, 2008).

The purpose of research. Investigate the fishbiological substantiation of the fishery for growing silver carp in polyculture with carp in the conditions of LLC "Kovcheg" of the Kyiv.

\section{Material and methods}

The experiment was conducted in Kyiv on two groups of fish (silver carp, carp) in two lakes -7 and 8 ha. The Vita River flows nearby, which is the source of water supply for this farm. The climate of this region is temperate-continental.

Average temperature in January: $-3.5{ }^{\circ} \mathrm{C}$, in July: $+20.5^{\circ} \mathrm{C}$. The absolute minimum is $-32.2^{\circ} \mathrm{C}$ (February 7 , 1929), the absolute maximum is $+39.9{ }^{\circ} \mathrm{C}$ (August 1898) (according to other sources: $+39.4{ }^{\circ} \mathrm{C}$ (July 30, 1936). The average annual rainfall is $649 \mathrm{~mm}$, the maximum precipitation falls in July $(88 \mathrm{~mm})$, the minimum - in October (35 mm).

In winter, snow cover is formed in Kyiv, the average height of the cover in February is $20 \mathrm{~cm}$, the maximum is $440 \mathrm{~cm}$. The growing season is 120 days. Geographic coordinates: north latitude - $50 \circ 26$ '; east longitude $30^{\circ} 34^{\prime}$ '; average height above sea level - $105 \mathrm{~m}$.

The city of Kyiv is located in the center of Eastern Europe on both banks of the Dnieper River, in its middle course, below the confluence of the left tributary - the Desna River. The originality and diversity of natural conditions in Kyiv are related to its location on the border of physical and geographical zones: forest-steppe and mixed forests. 
The northern part of the city is located in the Polissya lowland, the southwestern (right bank) - in the Dnieper Upland, the southeastern (left bank) - in the Dnieper lowland. The surface of the right-bank part of the city is an elevated plateau-like plain, divided by ravines and gullies, valleys of small rivers, and the left-bank part is a lowland plain. Typical landforms of the right bank are mountains (Danchuk, 2006).

The city of Kyiv and adjacent territories, geologically, is located in the zone of junction of two regional structures of the north-eastern slope of the Ukrainian Crystal Shield and the south-western side of the Dnieper-Donetsk depression. The boundary between them is the Dnieper fault zone of the northwestern extension. Due to this, Kyiv is in a fairly calm tectonic zone.

The soil cover of Kyiv is very diverse, given the diversity of natural conditions. The northern outskirts of the city, which tend to Polissya, are characterized by sodpodzolic soils, formed mainly under coniferous forests. The right-bank high part of the city is dominated by black soil, which are familiar to most of Ukraine. They were formed mainly on very peculiar loose, well-ventilated and relatively dry loams - forests. Dark gray forest soils formed under the canopy of deciduous forests are widespread in Kyiv's natural forest parks. The city of Kyiv is rich in water: there are significant reserves of groundwater; in addition, there is a large number of surface water bodies: rivers, lakes, ponds. In general, water bodies in the city occupy 6.7 thousand hectares, or $8.0 \%$ of the territory (Mushit \& Datsyuk, 2020).

An analysis of the water quality of the reservoir supplying the farm was carried out, during the study the temperature indicators of the water in the pond № 1 and № 2 were monitored, and the oxygen saturation of the pond was measured. During the study, ponds, hydraulic equipment, devices for measuring temperature and oxygen saturation, vehicles, fishing gear were also used, groups of carp and silver carp divers of different ages were also used.

\section{Results and discussion}

During the study, laboratory inspections of the water quality of the source of supply, namely the Dniper River, were carried out, the indicators are given in table. 1 .

\section{Table 1}

Water quality indicators of the water supply source of ponds № 1 and № 2 of the Dnieper

\begin{tabular}{lcc}
\hline \multicolumn{1}{c}{ Index } & $\begin{array}{c}\text { Normative values of water quality of } \\
\text { fishery ponds }\end{array}$ & $\begin{array}{c}\text { Hydrochemical indicators of water } \\
\text { quality of the Dnieper river }\end{array}$ \\
\hline Soluble oxygen, $\mathrm{mg} / \mathrm{l}$ & $4.0-6.0$ & $4.3-5.5$ \\
Color (degrees) & $\leq 20(35)$ & 48 \\
Turbidity $\left(\mathrm{mg} / \mathrm{dm}^{3}\right)$ & $\leq 0.58(2.03)$ & 3.0 \\
Residual bound chlorine $\left(\mathrm{mg} / \mathrm{dm}^{3}\right)$ & $\leq 1.2$ & - \\
Aluminium $\left(\mathrm{mg} / \mathrm{dm}^{3}\right)$ & $\leq 0.5$ & 0.04 \\
Oxidation $\left(\mathrm{mg} \mathrm{O} / \mathrm{dm}^{3}\right)$ & $\leq 5.0$ & 12.5 \\
Ferrum $\left(\mathrm{mg} / \mathrm{dm}^{3}\right)$ & $\leq 0.2(1.0)$ & 0.15 \\
Ammonium $\left(\mathrm{mg}^{3} / \mathrm{dm}^{3}\right)$ & $\leq 0.5(2.6)$ & 0.38 \\
Nitrates $\left(\mathrm{mg} / \mathrm{dm}^{3}\right)$ & $\leq 50.0$ & 1.6 \\
Nitrites $\left(\mathrm{mg} / \mathrm{dm}^{3}\right)$ & $\leq 0.5$ & 0.06 \\
pH $($ hydrogen indicator) & $6.5-8.5$ & 7.8 \\
Stiffness $\left(\mathrm{mg}-\mathrm{eq} / \mathrm{dm}^{3}\right)$ & $\leq 7$ & 3.4 \\
Manganese $\left(\mathrm{mg} / \mathrm{dm}^{3}\right)$ & $\leq 0.05(0.5)$ & 0.13 \\
Free ammonia NH, $\mathrm{mg} \mathrm{N} / 1$ & 0.05 & $0.02-0.03$ \\
\hline
\end{tabular}

The source is formed on the basis of own research results

Laboratory studies have shown that the source of water supply to the farm, namely the Dnieper River in some hydrochemical parameters slightly exceeds the norm. In addition, no pathogenic microflora and individual hydrochemical compounds were detected in the water of this farm (Bessonov \& Privezentsev, 2017). Laboratory indicators indicate that the water in the farm LLC "Kovcheg" meets the requirements for water quality in fish farms, table. 1.
So, we conclude that this farm is in a good ecological and climatic zone, the water quality in the ponds is within acceptable limits and it allows us to breed and reproduce marketable fish, namely carp, grass carp and some species of herbivorous fish. The area of the water mirror in the farm is 15 ha, of which it became pond1 and became № 2 .

We can see the percentage of ponds to the area of the farm in the table. 2

\section{Table 2}

The structure of the water mirror of the farm LLC "Kovcheg"

\begin{tabular}{lcc}
\hline Categories of ponds of the economy & The area of ponds, ha & $\%$ \\
\hline Ponds, in all & 15 & 100 \\
Pond №2 & 8 & 87.5 \\
Pond №1 & 7 & 12.5 \\
\hline
\end{tabular}

The source is formed on the basis of own research results 


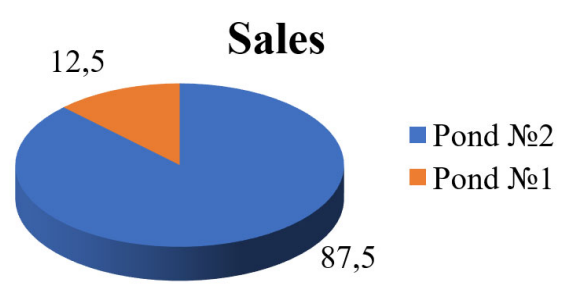

Fig. 1. The percentage of ponds of the farm LLC "Kovcheg"

The farm grows carp, silver carp and some herbivorous fish species. In pond fish farming, the use of polyculture of herbivorous fish makes it possible to increase the fish productivity of ponds.

In ponds, natural fish productivity to some extent depends on the size of primary products, which is determined, in particular, by the development of algae. Basically, the development of algae is constrained by the fact that the water lacks the necessary nutrients for their growth. Most often it is salts of phosphorus and nitrogen, which are contained in small amounts in pond water. In some cases, the development of plankton is delayed by the acid reaction of water or other reasons.

Most often it is salts of phosphorus and nitrogen, which are contained in small amounts in pond water. In some cases, the development of plankton is delayed by the acid reaction of water or other reasons. The composition of the pond water depends on the soil of the bed, because between the water and the soil there are continuous processes of metabolism of solutes, in particular nitrogen and phosphorus (Shcherbak, 2013; Biliavtseva, 2020). Under some conditions, phosphorus and nitrogen compounds are absorbed from the water by the soil of the pond, in others, on the contrary, come out of the soil into the water, enriching it (Gritsynyak et al., 2008; Mushit \& Datsyuk, 2020).

Therefore, to maintain the required level of medium seasonal biomass feed base ponds № 1 and № 2 farm workers make organic and mineral fertilizers table. 3 .

During the research in the farm the temperature in ponds № 1 and № 2 of the table was constantly monitored. 4,5 .

Table 3

Application of bird droppings and manure to pond № 1 and № 2

\begin{tabular}{ccccc}
\hline \multirow{2}{*}{ The month, the decade } & \multicolumn{3}{c}{ bird droppings } & \multicolumn{2}{c}{ bird droppings + manure 1:1 } \\
\cline { 2 - 5 } & $\mathrm{kg}$ & Multiplicity of application & $\mathrm{kg}$ & Multiplicity of application \\
\hline June: I & 10 & 3 & 10 & 5 \\
II & 15 & 5 & 15 & 8 \\
III & 15 & 8 & 20 & 8 \\
July: I & 15 & 8 & 20 & 8 \\
II & 15 & 8 & 26 & 8 \\
III & 25 & 8 & 33 & 8 \\
August: I & 20 & 8 & 25 & 8 \\
II & 15 & 5 & 20 & 20 \\
III & 15 & 5 & & \\
\hline
\end{tabular}

The source is formed on the basis of own research results

Table 4

The temperature indicators of pond № 1

\begin{tabular}{ccccccc}
\hline \multirow{2}{*}{ Year } & \multicolumn{5}{c}{ Month } \\
\cline { 2 - 6 } & May & June & July & August & September & October \\
\cline { 2 - 6 } & \multicolumn{5}{c}{ Fverage monthly temperature, ${ }^{\circ} \mathrm{C}$} \\
\hline 2019 & $15.8^{\circ} \mathrm{C}$ & $23.4^{\circ} \mathrm{C}$ & $19.9^{\circ} \mathrm{C}$ & $20.4^{\circ} \mathrm{C}$ & $16.6^{\circ} \mathrm{C}$ & $11.6^{\circ} \mathrm{C}$ \\
2020 & $11.9^{\circ} \mathrm{C}$ & $19.9^{\circ} \mathrm{C}$ & $21.6^{\circ} \mathrm{C}$ & $20.7^{\circ} \mathrm{C}$ & $18.1{ }^{\circ} \mathrm{C}$ & $13.2^{\circ} \mathrm{C}$ \\
\hline
\end{tabular}

The source is formed on the basis of own research results

Table 5

The temperature indicators of pond № 2

\begin{tabular}{ccccccc}
\hline \multirow{2}{*}{ Year } & \multicolumn{5}{c}{ Month } \\
\cline { 2 - 6 } & March & April & May & June & July & August \\
\cline { 2 - 6 } & \multicolumn{5}{c}{ Average monthly temperature, ${ }^{\circ} \mathrm{C}$} \\
\hline 2019 & $3.8^{\circ} \mathrm{C}$ & $8.2^{\circ} \mathrm{C}$ & $15.5^{\circ} \mathrm{C}$ & $23.2^{\circ} \mathrm{C}$ & $19.6^{\circ} \mathrm{C}$ & $20.2^{\circ} \mathrm{C}$ \\
2020 & $5.1^{\circ} \mathrm{C}$ & $7.4^{\circ} \mathrm{C}$ & $11.7^{\circ} \mathrm{C}$ & $19.8^{\circ} \mathrm{C}$ & $21.2^{\circ} \mathrm{C}$ & $20.6^{\circ} \mathrm{C}$ \\
\hline
\end{tabular}

The source is formed on the basis of own research results 


\section{Table 6}

Temperature indicators and the content of dissolved oxygen in the water of the pond № 1 using the device "Oximeter 7031"

\begin{tabular}{ccc}
\hline Date & Contents $\mathrm{O}_{2, \text { мг } / \text { л }}$ & $\mathrm{t}^{\circ}$ water, ${ }^{\circ} \mathrm{C}$ \\
\hline 1 & 2 & 3 \\
\hline 15.04 .2020 & 6,4 & $7.4^{\circ} \mathrm{C}$ \\
30.04 .2020 & 6,0 & $8.0^{\circ} \mathrm{C}$ \\
15.05 .2020 & 5,8 & $11.7^{\circ} \mathrm{C}$ \\
30.05 .2020 & 5,7 & $12.3^{\circ} \mathrm{C}$ \\
15.06 .2020 & 6,1 & $19.8^{\circ} \mathrm{C}$ \\
30.06 .2020 & 6,0 & $19.9^{\circ} \mathrm{C}$ \\
15.07 .2020 & 5,7 & $21.2^{\circ} \mathrm{C}$ \\
30.07 .2020 & 5,6 & $21.9{ }^{\circ} \mathrm{C}$ \\
15.08 .2020 & 5,5 & $20.6{ }^{\circ} \mathrm{C}$ \\
30.08 .2020 & 5,4 & $21.3{ }^{\circ} \mathrm{C}$ \\
15.09 .2020 & 6,0 & $18.1{ }^{\circ} \mathrm{C}$ \\
30.09 .2020 & 6,3 & $17.2^{\circ} \mathrm{C}$ \\
15.10 .2020 & 6,5 & $13.2{ }^{\circ} \mathrm{C}$ \\
30.10 .2020 & 6,5 & $11.8^{\circ} \mathrm{C}$ \\
\hline
\end{tabular}

The source is formed on the basis of own research results

The results of the study of pond №1 (Table 6) showed that the oxygen content is insignificantly different from the norms for fisheries. Oxygen decreased in pond № 1 due to increasing air temperature.

We are presents research data on oxygen-temperature indicators of the pond № 2 in the table. 7 .

\section{Table 7}

Temperature indicators and the content of dissolved oxygen in the water of the pond № 2 using the device "Oximeter 7031"

\begin{tabular}{ccc}
\hline Date & Contents $\mathrm{O}_{2, \text { мг } / \text { л }}$ & $\mathrm{t}^{\circ}$ water, ${ }^{\circ} \mathrm{C}$ \\
\hline 1 & 2 & 3 \\
\hline 15.04 .2020 & 6,1 & $7.3^{\circ} \mathrm{C}$ \\
30.04 .2020 & 6,0 & $8.0^{\circ} \mathrm{C}$ \\
15.05 .2020 & 5,6 & $11.5^{\circ} \mathrm{C}$ \\
30.05 .2020 & 5,5 & $12.2^{\circ} \mathrm{C}$ \\
15.06 .2020 & 6,1 & $19.8^{\circ} \mathrm{C}$ \\
30.06 .2020 & 5,9 & $19.8^{\circ} \mathrm{C}$ \\
15.07 .2020 & 5,6 & $21.4^{\circ} \mathrm{C}$ \\
30.07 .2020 & 5,4 & $22.0^{\circ} \mathrm{C}$ \\
15.08 .2020 & 5,7 & $20.7^{\circ} \mathrm{C}$ \\
30.08 .2020 & 5,2 & $21.4^{\circ} \mathrm{C}$ \\
15.09 .2020 & 6,3 & $18.2^{\circ} \mathrm{C}$ \\
30.09 .2020 & 6,1 & $17.3^{\circ} \mathrm{C}$ \\
15.10 .2020 & 6,4 & $13.3^{\circ} \mathrm{C}$ \\
30.10 .2020 & 6,3 & $11.9^{\circ} \mathrm{C}$ \\
\hline
\end{tabular}

The source is formed on the basis of own research results

The results of the study of the pond № 2 (Table 7) showed that the hydrological situation in the pond is slightly worse than in the previous one, but insignificant.

The most effective method of combating suffocation is aeration (saturation) of water with oxygen and constant monitoring of the dissolved oxygen in the water. In water bodies where commercial fish are grown, the flow in the pond is increased or liming is carried out with quicklime (Alimov, 2003).

Oxygen dissolved in water is a prerequisite for the existence of most organisms that inhabit water bodies. The main sources of oxygen for aerobic cells are molecular oxygen from the atmosphere and water. Only a small part of aquatic organisms, which belong mainly to microbes and protozoa, can live in the absence of oxygen in water.

The content of dissolved oxygen in the reservoir depends on the ratio of two opposite processes: the first enriches the water with oxygen, the second - reduces its content in water. The supply of molecular oxygen to water is due to its release by aquatic vegetation in the process of photosynthesis and its entry from the atmosphere (Gritsynyak, 2007).

Oxygen enrichment of the atmosphere of the upper layers of water occurs provided that in the water it is less than its normal saturation at the appropriate temperatures and atmospheric pressure.

The rate of propagation of gases in water is much lower than in air, so in standing water this process is very slow. Under conditions of strong currents, wind, splashing water, the process of oxygen saturation is significantly accelerated. The main source of water enrichment with molecular oxygen is photosynthesis of aquatic vegetation. Its intensity depends on 23 water temperature and lighting. Photosynthesis occurs mainly in the surface layers of water, well-lit and heated. Along with the enrichment of water with oxygen, processes occur at the same time that leads to its reduction in reservoirs (Joyner-Matos \& Chapman, 2013; Sherman \& Yevtushenko, 2011).

Almost all biochemical transformations that occur in water are related to oxygen consumption. Such reactions include: bacterial oxidation of organic substances and inorganic compounds, respiration of animals and plant organisms.

The amount of oxygen consumed directly by fish depends on both the species of fish and its age. In fish, there is a clear specificity of both the minimum amount of dissolved oxygen in the water, which can live fish, and the intensity of oxygen consumption during respiration.

During the study in this farm was measured by oxygen saturation of water with a special device "Oximeter 7031", measurement data are presented in table 6, 7 .

During the research in the farm of LLC "Kovcheg" calculations of stocking of pond № 2 with carp and silver carp and calculation of broodstock and repair youth for this farm were carried out.

For stocking pond No. 2 you need 750 pieces./ha. carp. Planting density in wintering ponds -750 thou$\mathrm{sand} / \mathrm{ha}$; the ratio of females and males is $1: 2$; the capacity of the farm is $5.2 \mathrm{c} /$ ha.

1. In order for the farm to be settle fish, the area of the pond is needed, and this is 8 hectares multiplied by 750 pieces $8 \times 750=6000$ pieces.

2. To determine the capacity of a given farm, the amount of carp which will be stocked with fish should be divided by the weight of a one-year-old, namely $6000 / 0.35=17142$ pieces.

3. The capacity of the farm must be divided by the weight of the two-year-old to calculate the number of two-year-olds $-17142 / 0.43=39865$ pieces.

4. The number of biennials must be multiplied by 100 and divided by the yield of biennials to determine the number of annuals $-39865 \times 100 / 85=46900$ pieces. 
5. To determine the number of annuals, you need to multiply the number of annuals by 100 and divide by the yield of annuals $-46900 \times 100 / 75=62533$ pieces.

6. To determine the number of larvae, the number of yearlings must be multiplied by 100 and divided by the yield of this year $-62533 \times 100 / 65=96204$ pieces.

7. To determine the number of broods (nests) you need to divide the number of larvae by the output of larvae from one nest) $-96204 / 50000=2$ pieces.

Table 8 shows different age groups of Carp, which need to be supplied to pond No. 2 of this farm.

\section{Table 8}

The results of the study for stocking pond No. 2 of the farm LLC "Kovcheg"

\begin{tabular}{lc}
\hline \multicolumn{1}{c}{ Groups of different ages of carp } & Quantity, pieces \\
\hline carp larvae & 96204 pieces \\
carp fingerlings & 62533 pieces \\
peer carp & 46900 pieces \\
commercial two-year-old carp & 39865 pieces \\
\hline The source is formed on the basis of own research results
\end{tabular}

Therefore, during the calculations (Table 8), we determined the required number of different age groups of carp, such as: carp larvae; this year's carp; annual carp for stocking pond № 2 .

\section{Table 9}

The total number of broodstock and repair young carp
We also calculated the need for broodstock and repair of young carp.

1. In order to be able to count the number of females, we need the number of larvae to go to the larvae from one female, and the same: $96204 / 100000=1$ female.

2 . For this purpose, the number of males is required $1 \times 2=2$

3. Number of pies $-1+2=3$ (add pies at once).

4. The number of pies with a reserve of $50 \%$ :

5. Females bark $-(1 \times 150) / 100=2$

6. Male bark $-(2 \times 150) / 100=3$

7. At the whole procreators $=3+3=5$

With a vibrating $25 \%$ of the herd, the number of plaques will change very often $-5 \times 25 / 100=2$, or the nests will change $-2 / 3=1$

Repairs are not available (Table 9 ) with such minds as follows:

The initial number of repair little boxes is $1 \times 90=90$ pieces.

The initial number of repair trinkets of the box $1 \times 8=80$ pieces.

The initial number of repair for years is $1 \times 8=80$ pieces.

The number of barks for replacement young growth is $90+80+80=250$ pieces.

\begin{tabular}{cccc}
\hline Index & Number of broodstock. pieces & Index & The total number of repair young stock, pieces \\
\hline Females & 1 & Repair biennials & 90 \\
Males & 2 & Repair three years & 80 \\
Reserve & 5 & Repair four years & 80 \\
Total & 8 & Total & 250 \\
\hline
\end{tabular}

The source is formed on the basis of own research results

Also in this farm calculations of stocking of a pond № 2 with a bighead and calculation of breeders and repair youth for this farm are carried out.

550 pieces/ha are required for stocking of pond № 2 thick-headed. Planting density in winter ponds -320 thousand/ha; the ratio of females and males $-1: 2$; the capacity of the farm is $5.2 \mathrm{c} / \mathrm{ha}$.

1. In order to stock the farm you need the area of the pond, which is 8 hectares multiplied by 550 pieces: $8 \times 550=4400$ pieces.

2. To determine the capacity of the farm requires the number of carp which will be stocked began to divide by the weight of the annual, namely $4400 / 0.30=14666$ pieces.

3 . To calculate the number of two-year-olds, you need to divide the capacity of the farm by the weight of twoyear-olds $-14666 / 0.15=97773$ pieces.

4. To determine the number of biennials, the number of biennials must be multiplied by 100 and divided by the yield of biennial) $-97773 \times 100 / 85=115027$ pieces.

5. To determine the number of annuals, you need to multiply the number of annuals by 100 and divide by the yield of annuals $-115027 \times 100 / 75=153369$ pieces.

6 . To determine the number of larvae, you need to multiply the number of larvae by 100 and divide by the yield of this year $-153369 \times 100 / 65=235952$ pieces.
7. To determine the number of broods (nests) you need to divide the number of larvae by the output of larvae from one nest) $-235952 / 50000=4$ pieces.

In the table 10 presents different age groups of silver carp, which need to stock the steel № 2 of this farm.

\section{Table 10}

The results of the study for stocking pond No. 2 of the farm LLC "Kovcheg"

\begin{tabular}{lc}
\hline \multicolumn{1}{c}{ Age groups of silver carp } & Quantity, pieces \\
\hline Larvae of silver carp & 235952 pieces \\
This year's bighead & 153369 pieces \\
One-year-old silver carp & 115027 pieces \\
Commodity biennials & 97773 pieces \\
\hline The source is formed on the basis of own research results
\end{tabular}

Therefore, during the calculations (Table 8), we determined the required number of different age groups of silver carp, such as: silver carp larvae; this year's silver carp; annuals of silver carp for stocking the pond № 2 .

We also calculated the need for broodstock and repair young silver carp.

1. In order to determine the number of females of silver carp, we need to divide the number of larvae by the 
output of the larva from one female, namely: $235952 / 100000=2$ females.

2. To determine the number of males need $-2 \times 2=4$

3. Number of broodstock $-2+4=6$ (add broodstock together).

4. The number of offspring, taking into account the reserve $50 \%$ :

5. Females of silver carp $-(2 \times 150) / 100=3$

6. Males of the silver carp $-(4 \times 150) / 100=6$

7. In general, the offspring $=3+6=9$

When culling $25 \%$ of the herd, the number of broodstock will change annually $-9 \times 25 / 100=3$, or nests will be replaced $-6 / 3=2$
Repair livestock (Table 11) under the following conditions will be as follows:

The total number of repair biennials $-2 \times 90=180$ pieces.

The total number of repair three-year-olds $2 \times 8=160$ pieces.

The total number of repair four-year-olds $2 \times 8=160$ pieces.

The total number of repair young cattle $180+160+160=500$ pieces.

Table 11

The total number of broodstock and repair young carp

\begin{tabular}{cccc}
\hline Index & Number of broodstock. pieces & Index & The total number of repair young stock, pieces \\
\hline Females & 1 & Repair biennials & 180 \\
Males & 2 & Repair three years & 160 \\
Reserve & 5 & Repair four years & 160 \\
Total & 8 & Total & 500 \\
\hline
\end{tabular}

The source is formed on the basis of own research results

So from table 11 we can see the number of broodstock that we need to breed fish on this farm.

\section{Conclusions}

1. The farm LLC "Kovcheg" is engaged in the cultivation and sale of carp and silver carp.

2. According to the fish-biological substantiation, the fish farm project for the cultivation of silver carp in polyculture with carp in the conditions of LLC "Kovcheg" in Kiev, the area of the farm occupies 15 hectares.

3. According to our studies, the hydrochemical conditions of the LLC "Kovcheg" reservoir and the food supply are satisfactory, and they make it possible to grow silver carp in polyculture with carp.

4. To implement the developed project of growing 39,865 pieces of commercial carp on 8 hectares of pond № 2 it is necessary to have 96.204 pieces of carp larvae, 62.533 pieces of this year's carp, 46.900 pieces of annual carp. In order to provide the farm with larvae in the planned year it is planned to have 3 broodstock.

5. To implement the developed project of growing 97773 pieces of commercial silver carp on 8 ha of pond № 2, it is necessary to have 235952 pieces of silver carp larvae, 153369 pieces of this year's silver carp, 115027 pieces of silver carp annuals. In order to provide the farm with larvae in the planned year it is planned to have 6 broodstock.

6. The state of labor protection, ecological conditions, hydrological conditions, hydrochemical conditions and in general the state of the environment in the farm LLC "Kovcheg" is satisfactory and contributes to the implementation of the developed project for growing carp in polyculture with silver carp.

7. The state of water quality in pond №1 and № 2 is within acceptable limits, which allows us to grow, breed and sell carp, silver carp and some other herbivorous fish species.
8. During the research, the temperature of the pond № 1 and № 2 was constantly monitored from March to October, we can see that in July and August the temperature in the ponds was the highest, but this did not lead to a significant deterioration of the fish.

9. During April-October in the pond № 1 and № 2 the water condition was monitored for oxygen saturation, the results of the study showed that in July-August due to the increase in temperature the oxygen in the ponds did not decrease significantly and we managed to solve it.

10. Therefore, it is necessary to recommend the management of LLC "Kovcheg" to implement the developed technology of growing carp in polyculture with silver carp in production.

\section{References}

Alimov, S. I. (2003). Fisheries of Ukraine: status and prospects. K.: Higher education (in Ukrainian).

Bessonov, N. M., \& Privezentsev, Yu. A. (2017). Fisheries hydrochemistry. M.: Agropromizdat (in Ukrainian).

Biliavtseva, V. V. (2020). The effect of feeding bvmd "Enervik" on the body of silver carp and carp. Slovak international scientific journal, 44, 49-52. URL: http://socrates.vsau.org/repository/getfile.php/25623.p df (in Slovakia).

Bobel, I., Pivtorak, J., \& Petryshak, R. (2018). Economic efficiency of growing commodity trout in farms in the Western Ukraine while feeding with forages Aller Aqua. Scientific Messenger of LNU of Veterinary Medicine and Biotechnologies. Series: Agri-cultural Sciences, 20(89), 71-74. doi: 10.32718/nvlvet8913.

Burgaz, M., Matvienko, T., Bezik, K., \& Soborova, O. (2019). The current state of fish market in Ukraine. Ukrainian Journal of Veterinary and Agricultural Sciences, 2(3), 6-10. doi: 10.32718/ujvas2-3.02. 
Burgaz, M., Matviienko, T., Soborova, O., Bezyk, K., \& Kudelina, O. (2019). The current state of fishing and extracting the living aquatic resources in the Black Sea region of Ukraine. Ukrainian Journal of Veterinary and Agricultural Sciences, 2(3), 23-27. doi: 10.32718/ujvas2-3.06.

Burhaz, M., Matviienko, T., Soborova, O., Bezyk, K., Kudelina, O., \& Lichna, A. (2020). Modern state of fish and fishery products export in Ukraine. Ukrainian Journal of Veterinary and Agricultural Sciences, 3(1), 21-26. doi: 10.32718/ujvas3-1.04.

Danchuk, V. V. (2006). Peroxidation in farm animals and poultry. Kamenets ABC (in Ukrainian).

Datsyuk, I., \& Mushit, S. (2020). Ways to improve commodity fish production. Slovak international scientific journal, 4(1), 21-50 (in Slovakia).

Geiko, L. M. (2010). Methodical recommendations for improving methods of rearing larvae of carp fish. Kyiv: DIA Publishing House.

Gritsinyak, I. I., Hrabko, M. I., \& Rivi, J. F. (2011). Fish productivity of growing ponds when fertilizing them with various organic fertilizers. Fisheries science of Ukraine, 4, 85-88 (in Ukrainian).

Gritsynyak, I. I. (2007). Scientific and practical foundations of rational feeding of fish. K.: My fish (in Ukrainian).

Gritsynyak, I. I., Nagornyuk, T. A., \& Tarasyuk, S. I. (2008). Genetic structure of breeds and breed groups of carp by individual genetic and biochemical systems. Fisheries science of Ukraine, 1, 29-35 (in Ukrainian).

Grynevych, N., Sliusarenko, A., Dyman, T., Sliusarenko, S., Gutyj, B., Kukhtyn, M., Hunchak, V., \& Kushnir, V. (2018). Etiology and histopathological alterations in some body organs of juvenile rainbow trout Oncorhynchus mykiss (Walbaum, 1792) at nitrite poisoning. Ukrainian Journal of Ecology, 8(1), 402-408. doi: 10.15421/2018_228.
Joyner-Matos, J., \& Chapman, L. (2013). Persisting in papyrus: Size, oxidative stress, and fitness in freshwater organisms adapted to sustained hypoxia. Comp Biochem Physiol A Mol Integr Physiol, 165(4), 405-416. doi: 10.1016/j.cbpa.2013.03.032.

Mukhina, N. V. (2008). Feed and biologically active feed additives for animals. M.: Colos (in Ukrainian).

Mushit, S., \& Datsyuk, I. (2020). The latest methods of reproduction of the owner. Polish journal of science, 31(1), 8-29 (in Poland).

Prysiazhniuk, N., Grynevych, N., Slobodeniuk, O., Kuzmenko, O., Tarasenko, L., Bevz, O., Khomiak, O., Horchanok, A., Gutyj, B., Kulyaba, O., Sachuk, R., Boiko, O., \& Magrelo, N. (2019). Monitoring of morphological parameters of Cyprinidae liver. Ukrainian Journal of Ecology, 9(3), 162-167. URL: https:/www.ujecology.com/articles/monitoring-ofmorphological-parameters-of-cyprinidae-liver.pdf.

Rudenko, O. P., Paranjak, R. P., Kovalchuk, N. A., Kit, L. P., Hradovych, N. I., Gutyj, B. V., Kalyn, B. M., Sukhorska, O. P., Butsiak, A. A., Kropyvka, S. I., Petruniv, V. V., \& Kovalska, L. M. (2019). Influence of seasonal factors on carp fish immune reactivity. Ukrainian Journal of Ecology, 9(3), 168-173. URL: https:/www.ujecology.com/articles/influence-ofseasonal-factors-on-carp-fish-immune-reactivity.pdf.

Shcherbak, V. I. (2013). Integrated water resources management: Nauk. Zbirnik. K.: DIA (in Ukrainian).

Sherman, I. M., \& Yevtushenko, M. Y. (2011). Theoretical foundations of fish farming. K: Urozhay (in Ukrainian).

Vlasov, V. A., \& Mustaev, S. V. (2004). Breeding of freshwater fish and crayfish. M.: LLC Astrel Publishing House.

Vovk, N. I., \& Bozhyk, V. Y. (2014). Ichthyopathology: textbook, K. Agroosvita (in Ukrainian). 